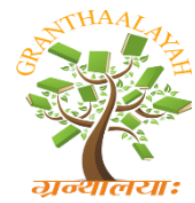

$$
\begin{aligned}
& \text { INTERNATIONAL JOURNAL OF RESEARCH - } \\
& \text { GRANTHAALAYAH } \\
& \text { A knowledge Repository }
\end{aligned}
$$

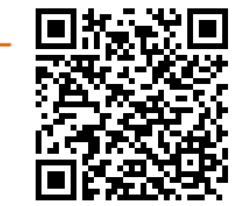

Social

\title{
READING COMPREHENSION IN RELATION TO ACADEMIC ACHIEVEMENT IN ENGLISH AMONG HIGHER SECONDARY STUDENTS
}

\author{
B. Menaka ${ }^{1}$, J.S. Justin Jebaraj ${ }^{2}$ \\ ${ }^{* 1}$ M.Ed Scholar, RVS College of Education, Sulur, India \\ ${ }^{2}$ Assistant professor in Tamil Education, RVS College of Education, Sulur, India
}

DOI: https://doi.org/10.29121/granthaalayah.v5.i5(SE).2017.1980

\begin{abstract}
Even though reading comprehension provides significant educational implications at present, it is seen that there is a decreasing trend in the general reading level of younger generation. The study aimed to examine the Reading comprehension in relation to academic achievement in English among students at higher secondary levels. The investigator adopted survey method to study the reading comprehension in relation to academic achievement in English among students at higher secondary levels. For this study a sample of 300 higher secondary students from five Govt and Private schools which are situated in and around Coimbatore district in Tamil Nadu were selected by the investigator using simple random sampling technique. The findings reveal that there is a significant relationship between reading comprehension and academic achievement in English among selected students at higher secondary levels.
\end{abstract}

Keywords: English; Academic Achievement; Language; Reading; Higher Secondary School.

Cite This Article: B. Menaka, and J.S. Justin Jebaraj. (2017). "READING COMPREHENSION IN RELATION TO ACADEMIC ACHIEVEMENT IN ENGLISH AMONG HIGHER SECONDARY STUDENTS.” International Journal of Research - Granthaalayah, 5(5)SE, 113-117. https://doi.org/10.29121/granthaalayah.v5.i5(SE).2017.1980.

\section{Introduction}

Reading is one of the four necessary important language skills for those learning English as a second or foreign language (ESL/EFL), for academic success, and for professional development. The ability to comprehend expository texts which make up the bulk of their foreign language reading materials is, therefore, very important for all of them. In reading a text, students meet with many problems obstructing their reading comprehension. For example, the problems related to background knowledge, cultural knowledge, and knowledge of text type. Background knowledge is the students' prior knowledge or knowledge of the world. If a reader lacks prior knowledge in reading a text, he cannot follow and understand it because he does not know what 
the text is about. A reader uses background knowledge to integrate new information from a text into his prior information. In addition, cultural differences affect reading comprehension. An unfamiliar cultural context and distinguishing between content knowledge of culture and knowledge of vocabulary cause problems in reading, because the reader does not clearly understand the other culture. In addition, an inadequate knowledge of text type is a problem in reading texts. The text type such as newspaper articles, fairy tales, and business letters, if the reader does not know what kind of the text, he cannot follow and understand what the text is about. A reader can understand a text if he is familiar with the text type.

\section{Design of the Study}

The investigators adopted the survey method to study the reading comprehension in relation to academic achievement in English among higher secondary students. For this study a sample of 300 higher secondary students from five Govt and Private schools which are situated in and around Coimbatore district in Tamil Nadu were selected by the investigator using simple random sampling technique. Tool on reading comprehension and academic achievement in English among higher secondary students were developed by investigator.

\section{HYPOTHESIS: 1}

There is no significant mean score difference in reading comprehension and academic achievement in English based on sex (Male \& Female) of selected higher secondary students.

Table 1: Means score difference and t-test of reading comprehension and academic achievement in English based on sex (Male \& Female) of selected higher secondary students.

\begin{tabular}{|c|c|c|c|c|c|c|c|c|c|}
\hline S.NO & SUBJECT & GENDER & $\mathbf{N}$ & Mean & S.D & df & $\begin{array}{l}\text { t- } \\
\text { value }\end{array}$ & $\begin{array}{l}\text { p- } \\
\text { value }\end{array}$ & $\begin{array}{l}\text { Res } \\
\text { ult }\end{array}$ \\
\hline \multirow[t]{2}{*}{1.} & \multirow{2}{*}{$\begin{array}{l}\text { READING } \\
\text { COMPREHENSO } \\
\mathbf{N}\end{array}$} & MALE & 158 & 33.94 & 6.970 & \multirow[b]{2}{*}{300} & \multirow[b]{2}{*}{1.025} & \multirow[b]{2}{*}{0.97} & \multirow[b]{2}{*}{ N.S } \\
\hline & & FEMALE & 142 & 33.08 & 7.549 & & & & \\
\hline \multirow[t]{3}{*}{2.} & \multirow{3}{*}{$\begin{array}{l}\text { ACADEMIC } \\
\text { ACHIEVEMENT }\end{array}$} & MALE & 157 & 60.04 & 13.797 & \multirow{3}{*}{300} & \multirow{3}{*}{-.136} & \multirow{3}{*}{0.06} & \multirow{3}{*}{ N.S } \\
\hline & & FEMALE & 142 & \multirow{2}{*}{60.29} & \multirow{2}{*}{18.034} & & & & \\
\hline & & TOTAL & 300 & & & & & & \\
\hline
\end{tabular}

The Table 1 shows that mean score difference in reading comprehension in relation to academic achievement in English based on sex of selected higher secondary students. The calculated tvalue is statistically not significant at 0.05 levels and hence, the hypothesis 1 is rejected. It can be concluded that there is no significant difference in reading comprehension in relation to academic achievement in English based on sex of selected higher secondary students. 


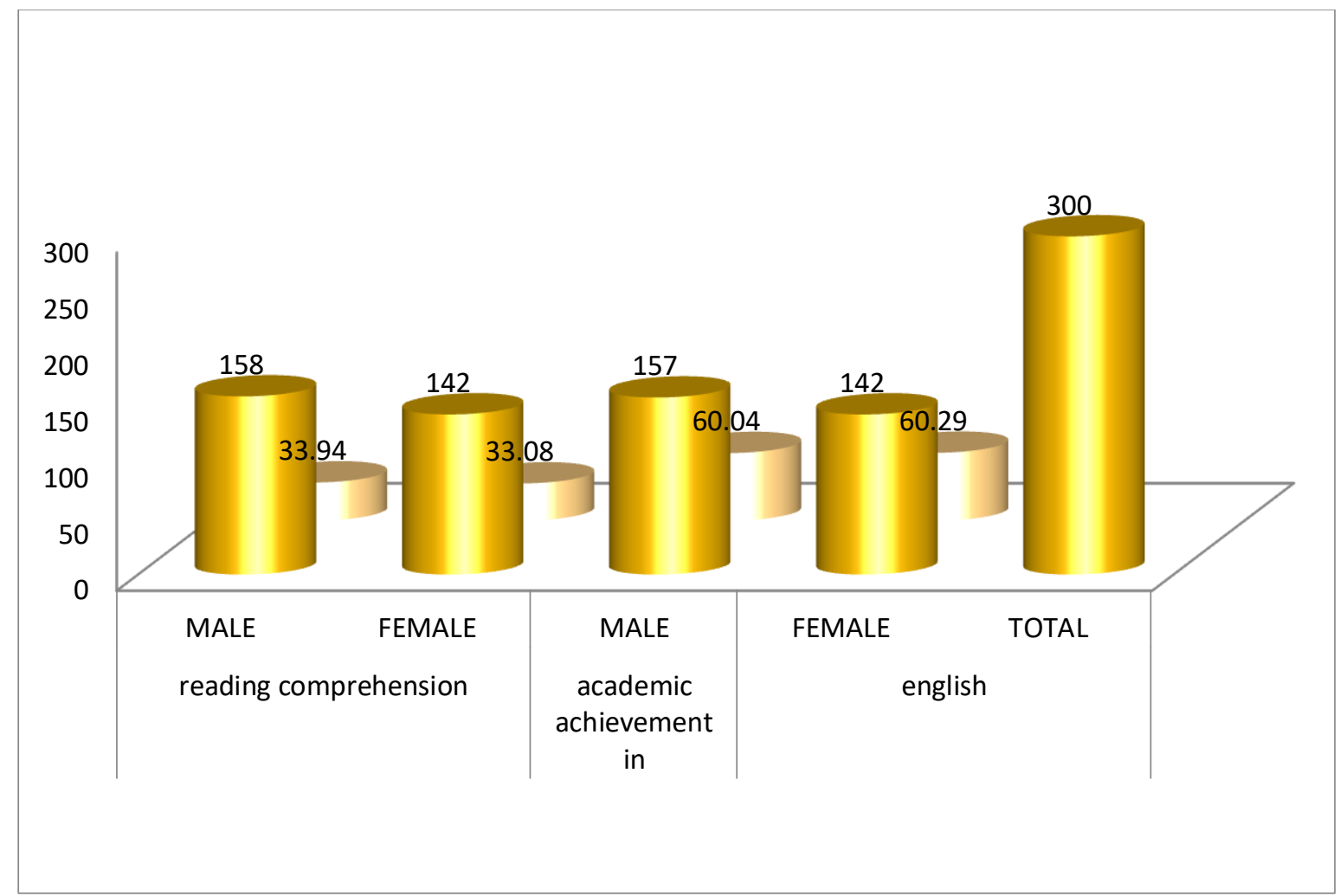

Chart 1: Mean Score Difference between Reading Comprehension and Academic Achievement in English Based on Gender

\section{HYPOTHESIS: 2}

There is no significant mean score difference in reading comprehension in relation to academic achievement in English based on medium (Tamil\& English) of selected higher secondary students.

Table 2: Means score difference and t-test of reading comprehension and academic achievement in English based on medium (Tamil\& English) of selected higher secondary students.

\begin{tabular}{|c|c|c|c|c|c|c|c|c|c|}
\hline S.NO & SUBJECT & MEDIUM & $\mathbf{N}$ & Mean & S.D & df & $\begin{array}{l}\text { t- } \\
\text { value }\end{array}$ & $\begin{array}{l}\text { p- } \\
\text { value }\end{array}$ & $\begin{array}{l}\text { Res } \\
\text { ult }\end{array}$ \\
\hline \multirow[t]{2}{*}{1.} & \multirow{2}{*}{$\begin{array}{l}\text { READING } \\
\text { COMPREHENSO } \\
\mathrm{N}\end{array}$} & TAMIL & 215 & 33.46 & 7.343 & \multirow[b]{2}{*}{300} & \multirow[b]{2}{*}{-.281} & \multirow[b]{2}{*}{.822} & \multirow[b]{2}{*}{ N.S } \\
\hline & & ENGLISH & 85 & 33.72 & 7.050 & & & & \\
\hline \multirow[t]{2}{*}{2.} & \multirow{2}{*}{$\begin{array}{l}\text { ACADEMIC } \\
\text { ACHIEVEMENT }\end{array}$} & TAMIL & 215 & 60.07 & 16.458 & \multirow[b]{2}{*}{300} & \multirow[b]{2}{*}{-.152} & \multirow[b]{2}{*}{.610} & \multirow[b]{2}{*}{ N.S } \\
\hline & & $\begin{array}{l}\text { ENGLISH } \\
\text { TOTAL }\end{array}$ & $\begin{array}{l}84 \\
300\end{array}$ & 60.38 & 14.558 & & & & \\
\hline
\end{tabular}

The Table 2 shows that mean score difference in reading comprehension in relation to academic achievement in English based on medium (Tamil\& English) of selected higher secondary students. The calculated t-value is statistically not significant at 0.05 levels and hence, the hypothesis 2 is rejected. It can be concluded that there is no significant difference in reading comprehension in relation to academic achievement in English based on medium (Tamil\& English) of selected higher secondary students. 


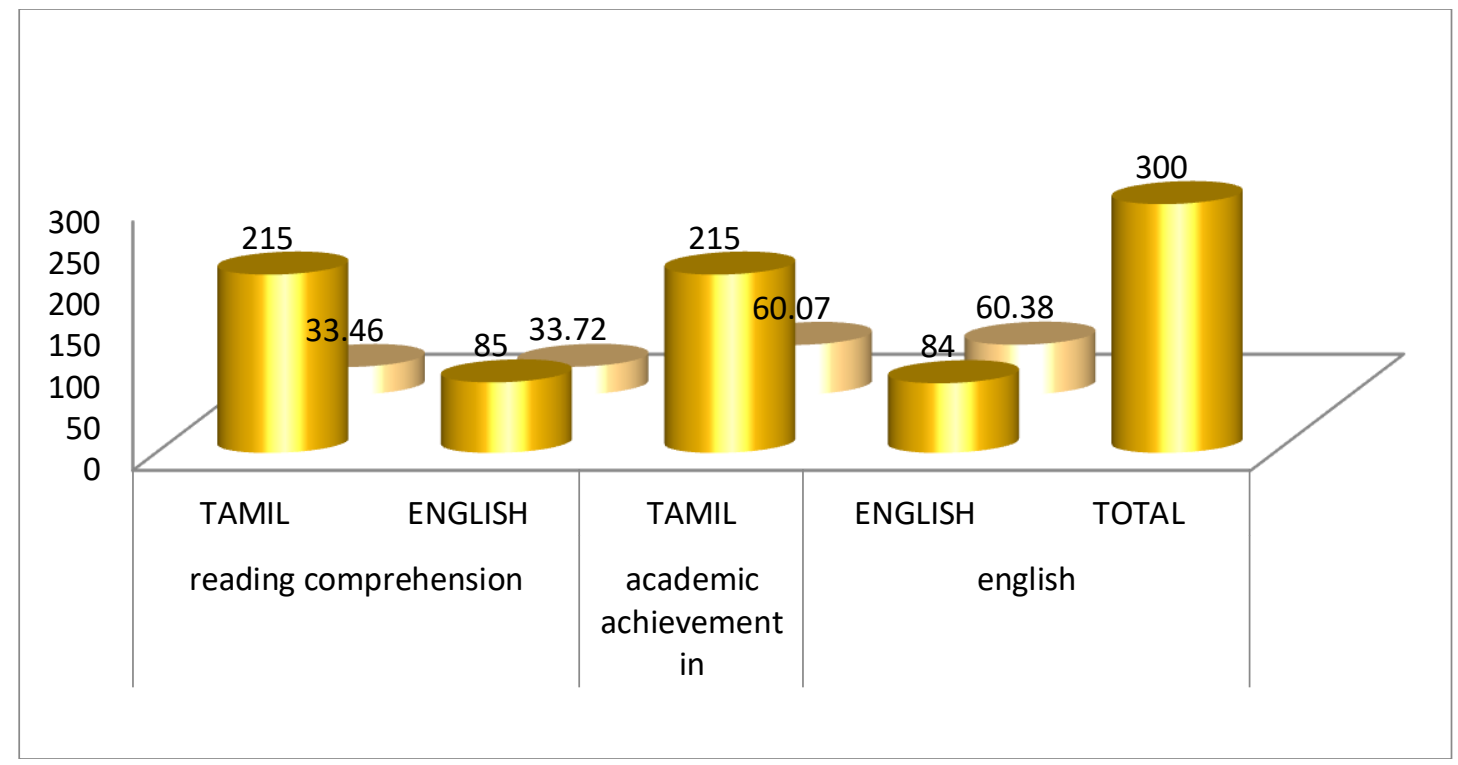

Chart 1: Mean Score Difference between Reading Comprehension and Academic Achievement in English Based on Medium

\section{HYPOTHESIS: 3}

There is no significant relationship between reading comprehension and academic achievement in English among the selected higher secondary students.

Table 3: Relationship between reading comprehension and academic achievement in English among the selected higher secondary students

\begin{tabular}{|c|c|c|c|c|}
\hline Variables & $\mathbf{N}$ & 'r' value & 'p' Value & Result \\
\hline $\begin{array}{l}\text { Reading } \\
\text { comprehension }\end{array}$ & 300 & & \multirow[b]{2}{*}{. 000} & \multirow[b]{2}{*}{ S. } \\
\hline $\begin{array}{l}\text { Academic } \\
\text { achievement in } \\
\text { English }\end{array}$ & 300 & & & \\
\hline
\end{tabular}

Table 3 exhibits the Pearson Correlation Coefficient value (0.00) which is significant at 0.01 level. Hence the Hypothesis 3 is rejected and it is inferred that there is a significant relationship between reading comprehension and academic achievement in English among the selected higher secondary students.

\section{Conclusion}

The findings reveal that there is no significant difference in reading comprehension in relation to academic achievement in English based on sex (Male \& Female) of selected higher secondary students. And There is no significant difference in reading comprehension in relation to academic achievement in English based on medium (Tamil \& English) of selected higher secondary students. Also it is found that there is a significant relationship between reading comprehension and academic achievement in English among the selected higher secondary students. 


\section{References}

[1] Alderson, C. J. (2002). Assessing Reading. The United Kingdom: Cambridge University Press. California: Wadsworth, A division of Thomson Learning, Inc.

[2] Golden, S. A. R. (2016). RURAL STUDENTS' ATTITUDE TOWARDS ENGLISH AS MEDIUM OF INSTRUCTION IN HIGHER EDUCATION - AN ANALYSIS. International Journal of Research, 3(Special Issue - 16), 1-10.

[3] Golden, S. A. R. (2017). Attitude of Students and Teachers towards E- Learning - An Analysis. Recent Research in Social Science \& Humanities, 1, 5-10.

[4] Golden, S. A. R. (2017). Recent Research In Social Science \& Humanities.

[5] Hayashi, K. (1999). "Reading strategies and extensive reading in EFL classes," RELC, 30(2), 114-133.

[6] Nassaji, H. (2003). "L2 vocabulary learning from context: strategies, knowledge sources, and their relationship with success in L2 lexical inferencing," Tesol Quarterly, 37(4), 645-670.

[7] Nuttall, C. (2000). Teaching reading skills in a foreign language. Oxford: Macmillan Publishers Limited.

[8] O' Donnell, M. P., \& Wood, M. (2004). Becoming a reader: A developmental approach Paribakht, T. S. (2004). "The role of grammar in second language lexical processing," RELC, 35(2), 149-160.

[9] Richardson, J. S., \& Morgan, R. F. (2003). Reading to learn in the content areas to reading instruction. 3 rd ed. Boston: Pearson Education, Inc. 